\title{
Efficacy of Chlorhexidine Alcohol over Aqueous Povidone Iodine in Prevention of Surgical Site Infection
}

\author{
Chhabda Tejinder Singh ${ }^{1}$, Gumaste Girish ${ }^{2}$, Chamle Gaurav ${ }^{3}$ \\ ${ }^{1,2,3}$ Department of General Surgery, MGM Medical College \& Hospital, N-6, Cidco, Aurangabad, Maharashtra, India
}

\begin{abstract}
Background: As it is justified skin flora has a significant role in surgical site infection. $20 \%$ of skin flora is beyond the conventional antiseptics hence there is need of a novel \& effective antiseptic preoperative skin preparation. This study focuses on efficacy of chlorhexidine alcohol for prevention of surgical site infection. Material \& methods: Comparative study of 200 patients done at MGM Medical College \& Hospital Aurangabad in surgery department patients were randomly divided in group-I (povidone-iodine) \& Group-II (Chlorhexidine) done from October 2013 to October 2015 where skin preparation done with respective antiseptics \& follow up taken till post-op day 7,the results are analyzed by chi-square test. Results: wound infection rates for Group-I was higher (30\%) as compared with Group II (14\%), and bacterial colonization rates in Group I (46.6\%) and in Group II (28.6\%). Conclusion: With use of chlorhexidine alcohol surgical site infections were reduced along with significant reduction in bacterial colonization. On the basis of this study we recommend wider use of chlorhexidine alcohol as an effective antiseptic for prevention of surgical site infections.
\end{abstract}

Keywords: Surgical site infection, Antiseptic, Chlorhexidine, Povidone-iodine

\section{Introduction}

Surgical site infection is considered as a major problem in the surgical field. There are various studies carried to compare efficacy of antiseptics showed alcoholic chlorhexidine gluconate is superior to povidone iodine in reducing surgical site infections $[1,2,3,4]$. As there are many factors for surgical site infection but it can be significantly lowered with the use of effective antiseptics, present study compares efficacy of alcoholic chlorhexidine versus aqueous povidone iodine in prevention of surgical site infection and reduction in bacterial colonization in infected wounds.

\section{Material \& Methods}

Randomized controlled study was conducted between october2013-october2015 in department of surgery, Mahatma Gandhi Mission Medical College and Hospital, Aurangabad. Patients were randomly divided in Group I (Povidone-iodine) \& Group II (Chlorhexidine) each group having 100 patients undergoing elective clean \& clean-contaminated surgeries. The pre operative skin preparation is done with povidone iodine IP 5\% w/v marketed as Betadine in group-I \& chlorhexidine gluconate $2.5 \% \mathrm{v} / \mathrm{v}$ in $70 \%$ propanol in groupII. In both the groups sterile saline swab culture taken from the incision site preoperatively as well as postoperatively (only where wound is infected). In cases where culture is positive antibiotic sensitivity is done along with morphological characteristics and differences in colonization rates were determined as a measure of efficacy of antiseptic regimen.

\section{Inclusion Criteria:}

1. Patients undergoing clean and clean contaminated elective surgery.
2. Patients of all ages and irrespective of sex.

3. Patients not having any focus of infection over the body

4. Patients irrespective of their socioeconomical status

\section{Exclusion Criteria:}

1. Emergency surgery

2. Immunocompromised patients and patients on steroids

3. Patients with septicemia and systemic illness

4. Malignancies or undergoing chemo \& radiotherapy.

5. Contaminated \& dirty surgeries in which viscous was opened were excluded from the study.

\section{Results}

Patients are selected irrespective of their age and sex with however in both the groups males outnumbered the females.

Table 1: Preoperative microbiological report

\begin{tabular}{|l|c|c|}
\hline Microbiological Report & $\begin{array}{c}\text { Group-I } \\
\text { Povidone iodine }\end{array}$ & $\begin{array}{c}\text { Group-II } \\
\text { Chlorhexidine }\end{array}$ \\
\hline & Percentage & Percentage \\
\hline No Growth & 80 & 90 \\
\hline Staph aureus & 08 & 05 \\
\hline Staph albus & 06 & 04 \\
\hline Klebsiella species & 01 & 00 \\
\hline Escherichia coli & 03 & 00 \\
\hline Bacillus Subtilis & 02 & 01 \\
\hline Total & 100 & 100 \\
\hline Chi square value & \multicolumn{2}{|c|}{6.01} \\
\hline P value & \multicolumn{2}{|c|}{0.305} \\
\hline
\end{tabular}

Above table showing growth in preoperative period in povidone iodine group $20 \%$ while in chlorhexidine group is $10 \%$ which is not significant chi square $6.01, \mathrm{P}-0.305$. The wound infection is calculated during or at $7^{\text {th }}$ post-op day. 


\section{International Journal of Science and Research (IJSR) \\ ISSN (Online): 2319-7064}

Index Copernicus Value (2013): 6.14 | Impact Factor (2014): 5.611

Table 2: Comparison of number of infected cases

\begin{tabular}{|c|c|c|c|c|c|c|}
\hline \multirow{2}{*}{$\begin{array}{c}\text { Wound infection } \\
\text { grade }\end{array}$} & \multicolumn{2}{|c|}{$\begin{array}{c}\text { Group-I (Povidone- } \\
\text { iodine) }\end{array}$} & \multicolumn{2}{c|}{$\begin{array}{c}\text { Group-II } \\
\text { (Chlorhexidine) }\end{array}$} & \multicolumn{3}{c|}{ Total } \\
\cline { 2 - 7 } & No. & $\%$ & No. & $\%$ & No. & $\%$ \\
\hline Grade 0 & 70 & 70.0 & 86 & 86.0 & 156 & 78.0 \\
\hline Infected & 30 & 30.0 & 14 & 14.0 & 44 & 22.0 \\
\hline Total & 100 & 100.0 & 100 & 100.0 & 200 & 1000 \\
\hline Chi-square value & \multicolumn{3}{|c|}{7.46} & & & \\
\hline P-value & \multicolumn{3}{|c|}{0.006} \\
\hline
\end{tabular}

\section{Comparison of infected cases}

Grade $0 \square$ Infected

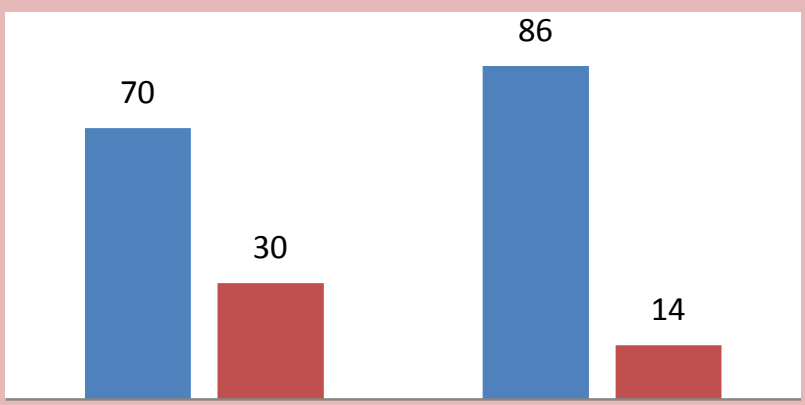

Group-I (Povidone-iodine) Group-II (Chlorhexidine)

Graph I: States total number of wound infected during postoperative period for povidone iodine is $30 \%$ and for chlorhexidine is $14 \%$, which is statistically significant, chisquare value $7.46 \& \mathrm{P}=0.006$.

Table 3: Post operative microbiological report

\begin{tabular}{|c|c|c|}
\hline $\begin{array}{c}\text { Microbiological } \\
\text { report }\end{array}$ & $\begin{array}{c}\text { Group I } \\
\text { (Povidone iodine) }\end{array}$ & $\begin{array}{c}\text { Group II } \\
\text { (Chlorhexidine) }\end{array}$ \\
\hline No Growth & No. & No. \\
\hline Staph aureus & 81 & 96 \\
\hline Staph albus & 08 & 02 \\
\hline Escherichia coli & 06 & 01 \\
\hline Bacillus subtilis & 03 & 00 \\
\hline Total & 100 & 01 \\
\hline Chi-square value & \multicolumn{2}{|c|}{11.8} \\
\hline P-value & \multicolumn{2}{|c|}{0.019} \\
\hline
\end{tabular}

Above table suggests Proportion of cases having growth in infected cases in povidone iodine group was $19 \%$ while in chlorhexidine group it was $4 \%$ which was significant 11.8 with P-0.019.

Table 4: Association of growth of organisms and post operative wound infection

\begin{tabular}{|c|c|c|c|c|}
\hline $\begin{array}{c}\text { Microbiologic } \\
\text { al report }\end{array}$ & \multicolumn{2}{|c|}{$\begin{array}{c}\text { Group- } \\
\text { (povidone iodine) }\end{array}$} & \multicolumn{2}{c|}{$\begin{array}{c}\text { Group-II } \\
\text { (Chlorhexidine) }\end{array}$} \\
\hline & Infection & $\begin{array}{c}\text { No } \\
\text { infection }\end{array}$ & $\begin{array}{c}\text { Infectio } \\
\mathrm{n}\end{array}$ & $\begin{array}{c}\text { No } \\
\text { infection }\end{array}$ \\
\hline No Growth & 11 & 70 & 10 & 86 \\
\hline Growth & 19 & 00 & 04 & 00 \\
\hline Total & 30 & 70 & 14 & 86 \\
\hline Chi square & 4.62 & \multicolumn{3}{|c|}{ P-value:0.032 } \\
\hline
\end{tabular}

Volume 4 Issue 12, December 2015
Association of growth of organisms and post operative wound infection

No Growth Growth Total

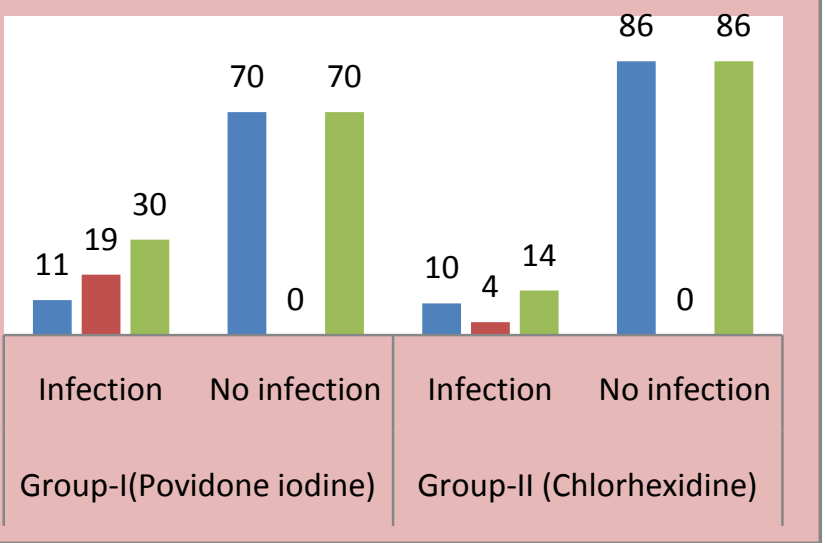

Graph II: Suggests association between the growth of organisms and postoperative wound infection where in group I out of 30 wound infections 19 has growth positive while 11 has no growth, In group II among 14 wound infections 4 has growth positive their chi-square value is 4.62 which is having statistical significance $(\mathrm{P}=0.032)$

\section{Discussion}

Surgical site infection in recent times is a significant cause in the morbidity of the patient leading to delay in the hospital stay. Proper skin disinfection however plays a vital role in reduction of surgical site infections. Chlorhexidine alcohol has advantage of residual action in the form of a protective film \& its bactericidal action is not altered by the presence of blood or serum. Connell et al in 1964 demonstrated povidone-iodine as a highly effective degerming agent which had a rapid lethal effect and was noninjurious to both normal skin and/or open wounds.[5] Hugo and Longworth (1964) observed that chlorhexidine is rapidly absorbed by bacterial cell \& Davies et al had observed that chlorhexidine exerted its action against wide range of vegetative bacteria both gram positive and gram negative and to lesser extent on spores [6]. A study by Ranjeet et al showed that surgical site infection in chlorhexidine group was $9.96 \%$ \& that of povidone-iodine was $15.95 \%$ [1]. Darouiche et al found chlorhexidine group $9.5 \%$ is better than povidone-iodine group $16.1 \%$ [2]. Lee et al done a meta-analysis of various RCT's comparing chlorhexidine with iodine for preoperative skin antisepsis revealed that chlorhexidine was associated with significant fewer surgical site infections along with reduction in the cost of antisepsis [7]. Grabsch EA et al, suggested excellent bactericidal efficacy of chlorhexidine over povidone iodine 


\section{International Journal of Science and Research (IJSR) \\ ISSN (Online): 2319-7064}

Index Copernicus Value (2013): 6.14 | Impact Factor (2014): 5.611

[8]. T.R. Brown et al concluded that wound infection rates were less with chlorhexidine spray technique $(6 \%)$ as compared to povidone iodine scrub or liquid (8.1\%) [9]. Patrick J. Culligan concluded that chlorhexidine gluconate was more effective than povidone-iodine in decreasing the bacterial colony counts that were found in the operative field for vaginal hysterectomy [10]. Bibbo $\mathrm{C}$ et al while doing ankle \& foot surgery concluded that chlorhexidine (79\%) and alcohol provide better reduction in bacterial carriage than povidone-iodine (38\%) [11]. Ostrander RV et al concluded that chlorhexidine alcohol is the most effective antiseptic for toes \& ankle surgery [12]. Paocharoen $\mathrm{V}$ et al concluded that bacterial colonization and postoperative surgical wound infection were significantly reduced in the chlorhexidine group than in povidone iodine group [13]. Magalini S et al in a comparative study concluded that chlorhexidine alcohol is easier and faster to use than povidone-iodine, requires less auxiliary material [14]. Jonia Amer-Alshiek Tahani Alshiek et al done a comparative study on patients undergoing caesarean section concluded that chlorhexidine $(10.43 \%)$ is better in reduction of surgical site infection as compared to povidone iodine (3.07\%) [15].

\section{Summary}

Present study conducted on 200 patients who were randomly divided in two groups irrespective of their age, sex \& socioeconomical status. In both the groups preoperative skin preparation done with respective antiseptic regimen. Sterile saline swab taken preoperatively as well post-operatively. The culture studies showed that in Group I, 19 cases out of 100 had bacterial growth. 6 had staphylococcus albus, 3 had Escherichia coli, 2 had bacillus subtilis (opportunistic pathogens) and in 8 had staphylococcus aureus (pathogenic bacteria) was grown. In Group II, only 4 cases out of 100 had bacterial growth. 2 had staphylococcus aureus, 1 had staphylococcus albus and 1 had bacillus subtilis. This showed that chlorhexidine was more effective in reducing colonization of site of incision (4\% in Group II as compared to $19 \%$ in group $\mathrm{I}) .(\mathrm{P}=0.019)$ Although in some cases, surgical site infections also occurred even when there was no growth on culture from site of incision after skin disinfection in Group I, 30 patients had post operative wound infection where as 14 patients in group II had post operative wound infection. This difference was attributed to difference in efficacy of both the antiseptic regimen thus proving chlorhexidine to be significantly more effective in reducing the rate of post operative wound infection ( $14 \%$ in group II as compared to $30 \%$ in group I) $(\mathrm{p}=0.006)$.

\section{Conclusion}

The results of the present study shows chlorhexidine gluconate $2.5 \% \mathrm{v} / \mathrm{v}$ in $70 \%$ propanol is nearly an ideal antiseptic due to:

- Broader antimicrobial spectrum than povidone iodine,

- It leaves a protective film where as povidone-iodine leaves no film,

- Rate of post-operative wound infections are much lower than povidone-iodine,
- Bacterial colonization is also significantly less than povidone-iodine.

Hence it can be safely concluded that chlorhexidine alcohol should be followed in preoperative skin preparation in clean $\&$ clean contaminated elective surgeries. Since the efficacy of this regimen was proved in reduction in incision site colonization and postoperative wound infection, it is prudent to use this regimen in contaminated and emergency surgeries.

\section{References}

[1] Ranjeet A. Patil "A Comparative Study Of Chlorhexidine-Alcohol Versus Povidone-Iodine For Surgical Site Antisepsis In Clean \& Clean Contaminated Cases" Journal of Medical Thesis 2013 July-Sep; 1(1) : 33

[2] Darouiche RO, Wall MJ, Itani KMF et al; Chlorhexidine-Alcohol versus Povidone- Iodine for Surgical Site Antisepsis. New Eng J Med 2010; 362(1): 18-26.

[3] Safia Bibi, Syed AslamShah, Shamim Qureshi, TaranumRuba Siddiqui et al "Is chlorhexidine-gluconate superior than Povidone-Iodine in preventing surgical site infections? A multicenter study" JPMA 65: 1197; 2015.

[4] Chatterjee A, Biswas R, Ghosh A,Trigunait p et al "A prospective comparative study of chlorhexidine-alchohol versus povidone-iodine for surgical site antisepsis in clean contaminated surgery" International journal of medical science and clinical Invention :2014;179-193

[5] James F. Connell and Louis M. Rousselot. 1964, Dec. "Povidone-Iodine: Extensive surgical evaluation of a new antiseptic agent." American Journal of Surgery. 108: 849-855.

[6] Hugo W.B. and Longworth A.R. 1964. "Some aspects of the mode of action of chlorhexidine." Brit. J. Pharm. Pharmacop. 16: 658.

[7] Ingi Lee; Rajender K. Agarwal; Bruce Y. Lee;Neil O. Fishman; Craig A et al Systematic Review and Cost Analysis Comparing Use of Chlorhexidine with Use of Iodine for Preoperative Skin Antisepsis to Prevent Surgical Site Infection in Chicago journal on behalf of The Society for Healthcare Epidemiology of America • Infect Control Hosp Epidemiol 2010; 31(12):1219-1229.

[8] Grabsch E.A., Mitchell D.J., Hooper J.and Turnidge J.D. 2004, Sep. "In use efficacy of a chlorhexidine in alcohol surgical sub: a comparative study." ANZ J Surg. 74(9): 769-72.

[9] Brown T.R., Clarence E. Ehrlich, Frederick B. Stehman, Alan M. Golichowski, James A. Madura and Harold E.E. 1984. "Clinical evaluations of chlorhexidine gluconate spray as compared with iodophor scrub for preoperative skin preparation." Surgery, Gynecology and Obstetrics; 158(4):363.

[10] Patrick J. C., Kari K., Miles M., Blackwell L. and James S. 2005, Feb. "A randomized trial that compared povidone iodine and chlorhexidine as 80 antiseptics for vaginal hysterectomy." American Journal of Obstetrics and Gynecology. 192(2) : 422-25.

[11]Bibbo C, Patel DV, Gehrmann RM, Lin SS. Chlorhexidine provides superior skin decontamination in foot and ankle surgery: a prospective randomized study. Clin Orthop 2005; 438:204-208. 


\section{International Journal of Science and Research (IJSR) \\ ISSN (Online): 2319-7064}

Index Copernicus Value (2013): 6.14 | Impact Factor (2014): 5.611

[12] Ostrander RV, Botte MJ, Brage ME. Efficacy of surgical preparation solutions in foot and ankle surgery. J Bone Joint Surg Am 2005;87(5):980-985.

[13] Paocharoen V, Mingmalairak C, Apisarnthanarak A. Comparison of surgical wound infection after preoperative skin preparation with $4 \%$ chlor-hexidine [correction of chlohexidine] and povidone iodine: a prospective randomized trial. J Med Assoc Thai 2009;92(7):898-902.

[14] Magalini S, Pepe G, Panunzi S, De Gaetano A, Abatini C, Di Giorgio A, Foco M, Gui D. (2013). Observational study on preoperative surgical field disinfection: Povidone-iodine and Chlorhexidine-alcohol. Eur Rev Med Pharmacol Sci; 17 (24): 3367-3375.

[15] Jonia Amer-Alshiek, Tahani Alshiek, Benny Almog et al "Can we reduce the surgical site infection rate in cesarean sections using a Chlorhexidine-based antisepsis protocol?" J Matern Fetal Neonatal Med.2013 Nov; 26(17):1749-52

\section{Author Profile}

Tejinder Singh Chhabda, MBBS, MS surgery now being associate professor at MGM Medical College \& Hospital, Aurangabad, Maharashtra, India

Gumaste Girish, MBBS, MS surgery Professor at MGM Medical College \& Hospital, Aurangabad, Maharashtra, India

Gaurav Chamle (Corresponding Author), MBBS, Post Graduate student in MS Surgery at MGM Medical College \& Hospital, Aurangabad, Maharashtra, India 